\title{
Harbour porpoise Phocoena phocoena abundance in the southwestern Baltic Sea
}

\author{
M. Scheidat ${ }^{1,2, *}$, A. Gilles ${ }^{1}$, K.-H. Kock ${ }^{3}$, U. Siebert ${ }^{1}$ \\ ${ }^{1}$ Forschungs- und Technologiezentrum Westküste, University of Kiel, Hafentörn 1, 25761 Büsum, Germany \\ ${ }^{2}$ Wageningen IMARES (Institute for Marine Resources and Ecosystem Studies), Postbus 167, 1790 AD Den Burg, \\ The Netherlands \\ ${ }^{3}$ Johann Heinrich von Thünen Institut, Institut für Seefischerei, Palmaille 9, 22767 Hamburg, Germany
}

\begin{abstract}
Harbour porpoise Phocoena phocoena is the only cetacean species resident in the Baltic Sea. At least 2 different subpopulations occur in this area, with a presumed demarcation line in the western Baltic Sea. Aerial surveys were conducted during different seasons in the years 2002 to 2006, to obtain estimates of porpoise abundance for the southwestern Baltic. Within the survey area, 3 strata were defined. In total, 46 surveys were completed for these strata. Abundance estimates and corresponding confidence intervals (CI) were calculated for each stratum separately for each survey. Density between areas varied seasonally and spatially, with the western study area (Kiel Bight) generally showing the highest density. Whenever all 3 strata were covered within 25 consecutive days, abundance for the overall survey area was calculated. Ten surveys met these criteria. Overall abundance in the western Baltic varied between surveys, with the lowest value in March 2003 (457 ind.; $95 \%$ CI: 0 to 1632), and the highest estimate in May 2005 (4610 ind.; $95 \%$ CI: 2259 to 9098). The results of all other surveys were in the range from 1352 to 2905 ind., with largely overlapping confidence intervals. Applying the only available bycatch estimates (which include no measure of precision) currently available for the German Baltic region, the percent of porpoise bycatch in the western Baltic lies within a range of 1.78 to $17.94 \%$ of the local population. To increase the precision of bycatch rates, more detailed bycatch estimates for this region are needed. Nevertheless, the results indicate that bycatch is a major threat to harbour porpoises throughout the western Baltic Sea.
\end{abstract}

KEY WORDS: Abundance $\cdot$ Distribution $\cdot$ Baltic Sea $\cdot$ Harbour porpoise $\cdot$ Aerial survey $\cdot$ Bycatch Resale or republication not permitted without written consent of the publisher

\section{INTRODUCTION}

The harbour porpoise Phocoena phocoena inhabits temperate to cold waters throughout the northern hemisphere and is the only cetacean species resident in the Baltic Sea (Berggren 1994, Kinze 1994, Berggren \& Arrhenius 1995a,b, Benke et al. 1998). The Baltic Sea is one of the world's largest brackish water basins (Voipio 1981). It is connected to the Kattegat Sea through the Oresund Strait, the Great and the Little Belt. The term Baltic Proper is used as formulated by Fonselius (1974), and includes the waters to the east of the Darss and Limhamn ridges, with the Bothnian Sea forming the northern border. A number of studies on genetics, morphology and contaminant load of porpoises indicate that several subpopulations of harbour porpoises occur in the Skagerrak-Kattegat Seas, the Belt Seas and the Baltic Proper (Kinze 1985, Andersen 1993, Børjesson \& Berggren 1997, Wang \& Berggren 1997, Berggren et al. 1999). Porpoises summering in the area east of the Darss and Limhamn ridges probably belong to a different population than the animals occurring in summer in the western Baltic Sea (Kiel and Mecklenburg Bights) (Tiedemann et al. 1996, Huggenberger et al. 2002). 
Surveys have shown densities of 0.644 ind. $\mathrm{km}^{-2}$ in the Belt Seas (Stratum I' in Hammond et al. 2002). In contrast, the density and range of porpoises are believed to be much reduced in the Baltic Proper (Andersen 1982, Skóra et al. 1988, Määttänen 1990, cf. Koschinski 2002). The reasons for this are unclear. Possible causes have been discussed by a number of authors (e.g. Berggren 1994, Kinze 1995, Teilmann \& Lowry 1996, Koschinski 2002) and include the commercial hunting of porpoises (e.g. in Poland and Denmark) that ended after the Second World War, high numbers of bycatch, increased mortality during severe ice winters and general habitat degradation (Skóra et al. 1988, Kinze 1995), as well as impaired health status when compared with other subpopulations (Siebert et al. 2001, 2006, Wünschmann et al. 2001). The impaired health status may be caused by high concentrations of contaminants (e.g. as described in Bruhn et al. 1999, Siebert et al. 1999, Beineke et al. 2005, Das et al. 2006).

One of the probable causes for the apparent failure of the Baltic Proper porpoise to recover lies in the continuing bycatch in fisheries. The incidental mortality in fishing gear is well documented for many parts of the Baltic Sea (e.g. Skóra et al. 1988, Christensen 1991, Skóra 1991, Berggren 1994, Kinze 1994, Kock \& Benke 1996). However, the impact of the bycatch numbers on porpoise populations can only be determined when reliable abundance estimates are available. The aim of the present study was to determine the abundance of harbour porpoises and to evaluate the effect of bycatch in the southwestern Baltic Sea.

\section{MATERIALS AND METHODS}

Study area. The study area in the southwestern Baltic Sea reaches from the German coastline north to the Danish islands. The area was divided into 3 strata (E: $4696 \mathrm{~km}^{2}$; F: $7248 \mathrm{~km}^{2}$; G: $10990 \mathrm{~km}^{2}$ ) (Fig. 1). One survey stratum could usually be surveyed within $1 \mathrm{~d}$ (5 to 9 flying hours).

Survey design and data acquisition. Surveys were carried out following standard line-transect methodology for aerial surveys (Hiby \& Hammond 1989, Buckland et al. 2001). The first survey was conducted in July 2002, the last survey in June 2006. Surveys were flown along a predetermined, systematic set of parallel transect lines with a random starting point, superimposed on the study area. The direction of transects was north-south to follow depth gradients, in order to minimise variance in encounter rate (Buckland et al. 2001). To ensure an adequate chance of harbour porpoise sightings, surveys were only conducted during good weather conditions with good visibilities $(>3 \mathrm{~km})$ and a sea state acccording to the Beaufort scale of $\leq 3$.

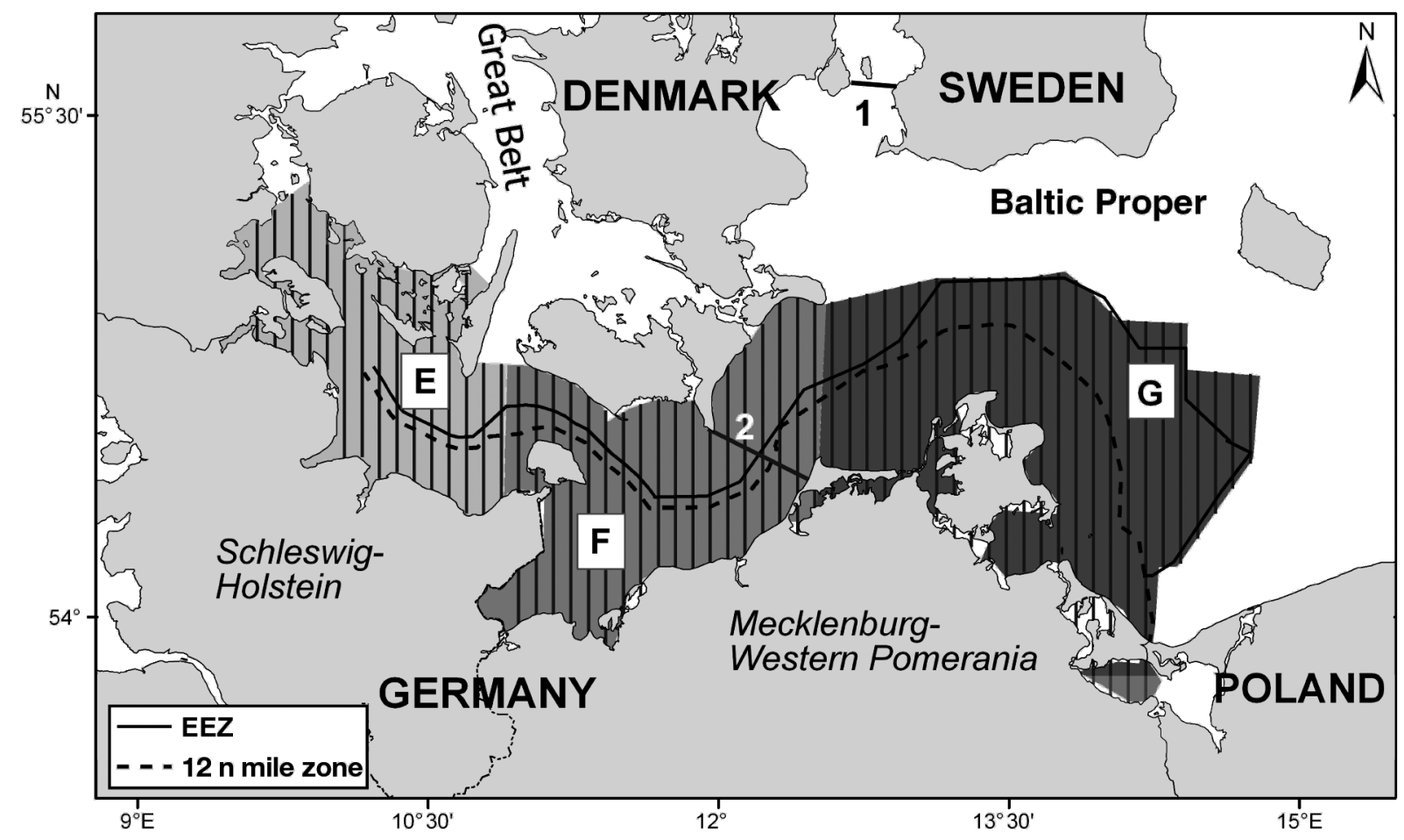

Fig. 1. Study strata for aerial surveys in the southwestern Baltic Sea. North-south transect lines in Strata E, F and G are indicated by solid grey lines. Transect lines are equispaced at intervals of $6 \mathrm{~km}$. 1: Limhamn ridge; 2: Darss ridge; EEZ: Exclusive Economic Zone 
The aircraft used was a high-wing 2-engine Partenavia 68 , equipped with bubble windows, flying at an altitude of $183 \mathrm{~m}$ (600 feet), with a speed of 167 to $186 \mathrm{~km} \mathrm{~h}^{-1}$ (90 to 100 knots). Data collection was based on the 'VOR' software designed by Lex Hiby and Phil Lovell and described in Hammond et al. (1995). Every $2 \mathrm{~s}$ the aircraft's position and time (to the nearest second) were recorded automatically onto a laptop computer connected to a GPS. Sighting information and details on environmental conditions were entered by a third person, the data recorder. Sea state (according to the Beaufort scale), glare, cloud cover (parts of 8), turbidity (judged visually on a scale of 0 [clear water with several meters of visibility] to 2 [very turbid water with no visibility under the surface]) and subjective sighting conditions ('good', 'moderate', or 'poor') were entered at the beginning of each transect and whenever any environmental condition changed. Sighting data were acquired by 2 observers located at the bubble windows left and right of the aircraft. Sighting data included declination angle measured from the aircraft abeam to the porpoise group, group size, presence of calves, behaviour, swimming direction, cue and reaction to the survey plane. The perpendicular distances from the transect to the group were later calculated from aircraft altitude and declination angle.

The aircraft surveyed using the 'racetrack' method, which involves some doubling-back to re-survey previously flown transect segments for the estimation of effective strip width (ESW; Burnham et al. 1980). The synchronous recording of GPS data, abeam times and declination angles allows the positions of pods sighted on the first and second sweeps of the plane ('overflights') to be calculated. When deciding which of the pods seen on the first and second overflights were duplicates, the likelihood of the observed positions can be maximised with respect to (1) the parameters of models for the distribution of intervals between successive pods; (2) the succession of a pod's near-surface and diving phases; (3) its horizontal displacement between the times it comes abeam of the first and second overflights; and (4) the probability of it being detected as a function of its perpendicular distance from the aircraft. However, as it is impossible to determine which pod sightings on the first and second overflights are duplicates, it is necessary to sum the likelihood over all possible pairings. Some of the sighting times from the 2 overflights are too far apart to be duplicates. The remaining sightings form groups within which pairs of sightings from the first and second overflights may or may not be of the same pod. A recursive code was used to generate all possible pairings of sightings within each group (including the special case of no duplicates at all). These arrangements form an exhaustive set of mutually exclusive events so that the probability for the observed sighting positions equals the sum of the probabilities for each possible arrangement. In this way we calculated the likelihood for the data on each section of the survey conducted under consistent conditions; the log likelihood for the entire survey was obtained as the sum of the log likelihood for each section. Further details of the racetrack method and the analyses are described in Hiby \& Lovell (1998) and Hiby (1999).

Synchronous recording of GPS data and sighting conditions allows the sighting locations to be assigned to sections of effort completed under consistent conditions (good and moderate) and, hence, allows the estimates of ESW appropriate to those conditions to be applied to those sections. The large number of free parameters involved in estimating ESW meant that it was not possible to derive estimates for $>2$ levels of sighting conditions. Subjective assessment of 'good' and 'moderate' conditions, assessed separately to the left and right of the transect, was chosen to define the sections completed under consistent conditions.

Data analysis. Only transects flown in 'good' or 'moderate' conditions were considered in the analysis. Detection curves and estimates of ESW were found to be similar under similar conditions in different years, so aerial survey data from 2002 to 2006 were pooled to provide an estimate of ESW for good and for moderate conditions.

Investigation of possible school size-bias indicated that no such bias was present. The mean school size was therefore estimated using the mean of the observed school sizes separately within each stratum.

Animal abundance in stratum $v$ was estimated using a Horvitz-Thompson-like estimator as:

$$
\hat{N}_{v}=\frac{A_{V}}{L_{V}}\left(\frac{n_{g s v}}{\hat{\mu}_{g}}+\frac{n_{m s v}}{\hat{\mu}_{m}}\right) \bar{S}_{V}
$$

where $A_{V}$ is the area of the stratum, $L_{V}$ is the length of transect line covered on-effort in good or moderate conditions, $n_{g s v}$ is the number of sightings that occurred in good conditions in the stratum, $n_{m s v}$ is the number of sightings that occurred in moderate conditions in the stratum, $\hat{\mu}_{g}$ is the estimated total effective strip width in good conditions, $\hat{\mu}_{m}$ is the estimated total effective strip width in moderate conditions and $\bar{S}_{V}$ is the mean observed school size in the stratum.

Group abundance by stratum was estimated by $\hat{N}_{V \text { (group) }}=\hat{N}_{V} / \bar{S}_{V}$. Total animal and group abundances were estimated by

$$
\hat{N}=\sum_{V} \hat{N}_{V} \text { and } \hat{N}_{\text {(group) }}=\sum_{V} \hat{N}_{V(\text { group })}{ }^{\prime}
$$

respectively. Densities were estimated by dividing the abundance estimates by the area of the associated stratum. Mean group size across strata was estimated by $\hat{E}[s]=\hat{N} / \hat{N}_{(\text {group })}$. 
Coefficients of variation (CV) and 95\% confidence intervals (CI) were estimated by a non-parametric bootstrap test (999 replicates) within strata, using transects as the sampling units. The variance due to estimation of ESW was incorporated using a parametric bootstrap procedure that assumes the ESW estimates in good and moderate conditions to be normally distributed random variables. For each bootstrap pseudosample of transect lines, a bivariate lognormal random variable was generated from a distribution with a mean and a variance-covariance matrix equal to those estimated by L. Hiby (pers. comm.), i.e.

$$
\hat{\mu}=(0.153,0.054) \text { and } \hat{\Sigma}=\left(\begin{array}{lr}
0.452^{2} & 0.000721 \\
0.000721 & 0.0162^{2}
\end{array}\right)
$$

This was used as the ESW for the pseudo-sample. The $95 \%$ CIs were calculated using the percentile method.

\section{RESULTS}

In the study period from 2002 to 2006, 43 surveys were conducted: 12 in Stratum E, 18 in Stratum F and 13 in Stratum G. Combined survey effort for all strata was $32448 \mathrm{~km}$; the total number of sightings was 363 and the total number of animals was 516. An overview of all sightings in the study area is given in Fig. 2.
The selected detection function, using Akaike's information criterion (AIC), was a hazard rate model with sea state, turbidity, subjective sighting condition and observer as covariates providing the best fit. Using this functional form, L. Hiby (pers. comm.) estimated total ESW $(\times 2$, including $\mathrm{g}(0))$ to be $0.153 \mathrm{~km}(\mathrm{SD}=$ 0.0452 ) under good conditions and $0.054 \mathrm{~km}$ ( $\mathrm{SD}=$ 0.0162) under moderate conditions, with estimated covariance of 0.000721 . The $g(0)$ values were thus 0.37 for good sighting conditions and 0.14 for moderate sighting conditions. The resulting half-strip widths (excluding $\mathrm{g}(0)$ ), thus, are $0.207 \mathrm{~km}$ in good and $0.193 \mathrm{~km}$ in moderate sighting conditions.

Density (animals $\mathrm{km}^{-2}$ ), CIs and CVs were calculated for each survey and are listed in Table 1 . The survey in July 2002 showed densities of $>1$ porpoise $\mathrm{km}^{-2}$ in Stratum G, caused by a fairly high number of aggregated sightings within a small area on the Oder Bank in the Pomeranian Bight. Such an occurrence of porpoises could not be confirmed after 2002, although coverage of the stratum was high. When excluding this unusual outlier, Stratum G showed the lowest sighting rates, as well as estimated densities of $<0.06$ porpoises $\mathrm{km}^{-2}$.

A survey of the entire Baltic Sea study area was considered to be complete, when (1) all 3 strata were surveyed within a period of 25 consecutive days and

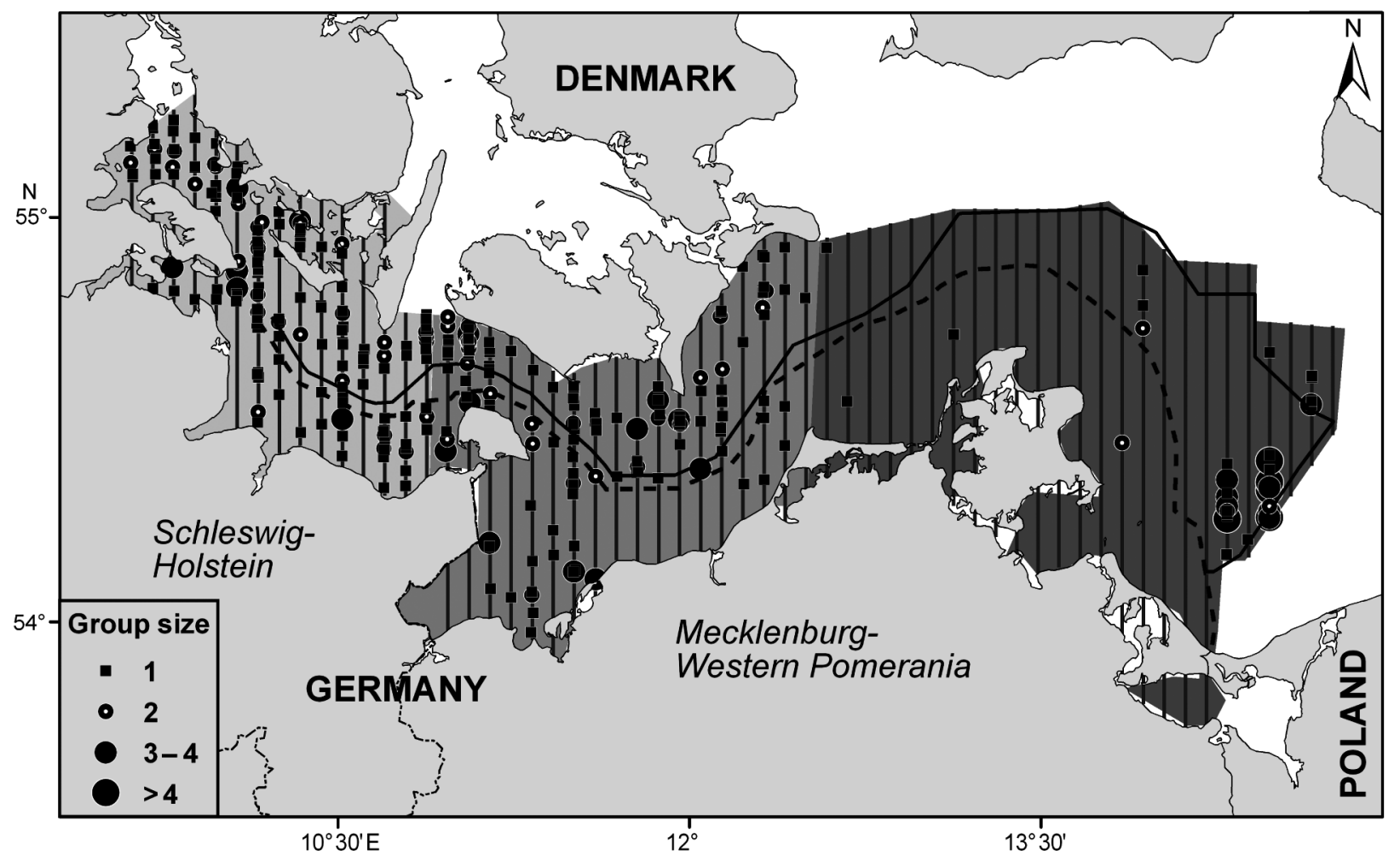

Fig. 2. Overview of all tracklines covered and harbour porpoise Phocoena phocoena sightings made in the study area. The area between the dashed and solid lines indicates the exclusive economic zone (EEZ) of Germany 
Table 1. Survey dates, survey effort and number of harbour porpoise sightings and animals. Mean group size and estimated density are given for each survey. CV: coefficient of variation; CI: confidence interval

\begin{tabular}{|c|c|c|c|c|c|c|}
\hline $\begin{array}{l}\text { Survey date } \\
\text { (dd-mm-yy) }\end{array}$ & $\begin{array}{c}\text { Effort } \\
(\mathrm{km})\end{array}$ & $\begin{array}{l}\text { No. of } \\
\text { sightings }\end{array}$ & $\begin{array}{l}\text { No. of } \\
\text { ind. }\end{array}$ & $\begin{array}{l}\text { Mean group } \\
\text { size }\end{array}$ & $\begin{array}{l}\text { Density (ind. km-2) } \\
\text { (95\% CI low-high) }\end{array}$ & $\mathrm{CV}$ \\
\hline \multicolumn{7}{|c|}{ Western Baltic (Kiel Bight): Stratum E } \\
\hline 28-08-02 & 387 & 5 & 9 & 1.80 & $0.152(0.00-0.42)$ & 0.65 \\
\hline $22-03-03$ & 732 & 1 & 1 & 1.00 & $0.009(0.00-0.40)$ & 1.12 \\
\hline $28-06-03$ & 503 & 21 & 26 & 1.24 & $0.367(0.17-0.80)$ & 0.39 \\
\hline $18-07-04$ & 474 & 4 & 5 & 1.25 & $0.132(0.02-0.35)$ & 0.61 \\
\hline 04-09-04 & 611 & 13 & 15 & 1.15 & $0.206(0.09-0.47)$ & 0.40 \\
\hline 20-03-05 & 727 & 3 & 5 & 1.67 & $0.100(0.00-0.37)$ & 0.98 \\
\hline $22-05-05$ & 794 & 48 & 61 & 1.27 & $0.636(0.30-1.35)$ & 0.37 \\
\hline $19-06-05$ & 787 & 35 & 42 & 1.20 & $0.422(0.18-0.96)$ & 0.43 \\
\hline 03-09-05 & 647 & 8 & 15 & 1.88 & $0.256(0.08-0.59)$ & 0.48 \\
\hline $16-04-06$ & 702 & 16 & 24 & 1.50 & $0.249(0.06-0.60)$ & 0.53 \\
\hline $13-05-06$ & 757 & 3 & 3 & 1.00 & $0.026(0.00-0.07)$ & 0.59 \\
\hline 10-06/11-06-06 & 701 & 11 & 12 & 1.09 & $0.186(0.07-0.43)$ & 0.45 \\
\hline Total & 7822 & 168 & 218 & & & \\
\hline \multicolumn{7}{|c|}{ Western Baltic (Mecklenburg Bight): Stratum F } \\
\hline $15-08-02$ & 659 & 7 & 9 & 1.29 & $0.113(0.00-0.38)$ & 0.81 \\
\hline 05-09-02 & 559 & 2 & 3 & 1.50 & $0.035(0.00-0.10)$ & 0.72 \\
\hline $30-10-02$ & 316 & 3 & 3 & 1.00 & $0.138(0.01-0.38)$ & 0.64 \\
\hline $10-12-02$ & 553 & 2 & 3 & 1.50 & $0.100(0.00-0.30)$ & 0.73 \\
\hline $20-03-03$ & 571 & 2 & 5 & 2.50 & $0.057(0.00-0.21)$ & 1.05 \\
\hline $17-06 / 18-06-03$ & 735 & 0 & 0 & - & $0(-)$ & - \\
\hline $01-08-03$ & 432 & 7 & 11 & 1.57 & $0.254(0.05-0.69)$ & 0.59 \\
\hline $16-07 / 18-07-04$ & 675 & 12 & 16 & 1.33 & $0.178(0.07-0.41)$ & 0.41 \\
\hline 02-09-04 & 935 & 16 & 28 & 1.75 & $0.218(0.09-0.48)$ & 0.42 \\
\hline $16-01 / 03-02-05$ & 643 & 0 & 0 & - & $0(-)$ & - \\
\hline $13-04-05$ & 548 & 1 & 1 & 1.00 & $0.034(0.00-0.12)$ & 0.99 \\
\hline $13-05-05$ & 1043 & 24 & 31 & 1.29 & $0.224(0.08-0.52)$ & 0.45 \\
\hline 03-06-05 & 862 & 14 & 16 & 1.14 & $0.121(0.02-0.38)$ & 0.68 \\
\hline 06-09-05 & 578 & 12 & 14 & 1.17 & $0.207(0.02-0.49)$ & 0.54 \\
\hline $15-01 / 16-01-06$ & 607 & 0 & 0 & - & $0(-)$ & - \\
\hline $19-04 / 24-04-06$ & 929 & 6 & 7 & 1.17 & $0.064(0.01-0.18)$ & 0.64 \\
\hline $10-05-06 / 15-05-06$ & 1123 & 24 & 33 & 1.38 & $0.236(0.09-0.55)$ & 0.45 \\
\hline $11-06 / 12-06-06$ & 681 & 26 & 28 & 1.08 & $0.345(0.15-0.80)$ & 0.45 \\
\hline Total & 12449 & 158 & 208 & & & \\
\hline \multicolumn{7}{|c|}{ Baltic Proper (Pomeranian Bight): Stratum G } \\
\hline $12-07-02$ & 726 & 32 & 84 & 2.63 & $1.016(0.06-3.19)$ & 0.73 \\
\hline 05-11-02 & 465 & 0 & 0 & - & $0(-)$ & - \\
\hline $11-12-02$ & 493 & 0 & 0 & - & $0(-)$ & - \\
\hline $21-03 / 28-03-03$ & 1143 & 0 & 0 & - & $0(-)$ & - \\
\hline $07-06 / 17-06-03$ & 683 & 0 & 0 & - & $0(-)$ & - \\
\hline $16-07 / 17-07-04$ & 831 & 1 & 1 & 1.00 & $0.008(0.00-0.03)$ & 1.06 \\
\hline 03-09-04 & 1147 & 0 & 0 & - & $0(-)$ & - \\
\hline $14-04-05$ & 647 & 2 & 3 & 1.5 & $0.058(0.00-0.20)$ & 0.84 \\
\hline $11-05 / 12-05-05$ & 1562 & 0 & 0 & - & $0(-)$ & - \\
\hline 09-06-05 & 1595 & 1 & 1 & 1.00 & $0.004(0.00-0.02)$ & 1.07 \\
\hline 05-09/07-09-05 & 1112 & 1 & 1 & 1.00 & $0.006(0.00-0.02)$ & 1.13 \\
\hline $24-04 / 25-04-06$ & 861 & 0 & 0 & - & $0(-)$ & - \\
\hline $10-05 / 11-05-06$ & 912 & 0 & 0 & - & $0(-)$ & - \\
\hline Total & 12177 & 37 & 90 & & & \\
\hline
\end{tabular}

(2) representative coverage of the transect lines in good or moderate conditions was achieved.

Ten surveys met these criteria, and we were able to estimate abundance for March 2003, March/April 2005, April 2006, May (2005 and 2006), June (2003 and 2005),
July 2004 and September (2004 and 2005). The resulting abundance estimates are listed in Table 2. In March 2003, the abundance estimate was lowest with 457 ind. For all other studies, the abundance estimates for the overall study area varied between 1635 and 4610 ind. 
Table 2. Overall abundance estimates for the surveys in the entire study area (Strata E, F and G) of the Baltic Sea (95\% confidence intervals $[\mathrm{CI}]$ and coefficients of variation $[\mathrm{CV}]$ both based on bootstrap estimates). Survey length indicates the time period (in days) in which the survey was completed. Calculation of bycatch rates per survey was based on an estimated bycatch of 82 (Rubsch \& Kock 2004). n.a.: not applicable

\begin{tabular}{|c|c|c|c|c|c|c|c|}
\hline Survey & $\begin{array}{l}\text { Survey length } \\
\text { (d) }\end{array}$ & $\begin{array}{l}\text { Effort } \\
(\mathrm{km})\end{array}$ & Abundance & $\mathrm{CV}$ & CI low & CI high & $\begin{array}{c}\text { Percent bycatch } \\
\text { (\% bycatch rate for } \mathrm{CI} \text { ) }\end{array}$ \\
\hline Mar 2003 & 8 & 2446 & 457 & 0.97 & 0 & 1632 & $\begin{array}{c}17.94 \\
\text { (n.a. }-5.02)\end{array}$ \\
\hline Jun 2003 & 21 & 1921 & 1726 & 0.39 & 778 & 3750 & $\begin{array}{c}4.75 \\
(10.54-2.19)\end{array}$ \\
\hline Jul 2004 & 2 & 1980 & 2001 & 0.39 & 916 & 4318 & $\begin{array}{c}4.10 \\
(8.95-1.90)\end{array}$ \\
\hline Sep 2004 & 2 & 2693 & 2547 & 0.36 & 1312 & 5461 & $\begin{array}{c}3.22 \\
(6.25-1.50)\end{array}$ \\
\hline Mar-Apr 2005 & 25 & 1922 & 1352 & 0.61 & 230 & 3840 & $\begin{array}{c}6.07 \\
(35.65-2.14)\end{array}$ \\
\hline May 2005 & 11 & 3400 & 4610 & 0.35 & 2259 & 9098 & $\begin{array}{c}1.78 \\
(3.63-0.90)\end{array}$ \\
\hline Jun 2005 & 16 & 3244 & 2905 & 0.41 & 1308 & 6384 & $\begin{array}{c}2.82 \\
(6.27-1.28)\end{array}$ \\
\hline Sep 2005 & 4 & 2337 & 2763 & 0.41 & 1193 & 5902 & $\begin{array}{c}2.97 \\
(6.87-1.39)\end{array}$ \\
\hline Apr 2006 & 8 & 2492 & 1635 & 0.45 & 607 & 3560 & $\begin{array}{c}5.02 \\
(13.51-2.30)\end{array}$ \\
\hline May 2006 & 5 & 2792 & 1833 & 0.44 & 752 & 4225 & $\begin{array}{c}4.47 \\
(10.90-1.94)\end{array}$ \\
\hline
\end{tabular}

\section{DISCUSSION}

\section{Density and abundance}

Few abundance estimates for the study area are available. In July 1994 the Small Cetacean abundance in the european Atlantic and North Sea and adjacent waters (SCANS) project estimated the abundance of porpoises Phocoena phocoena in the North Sea and adjacent waters (Hammond et al. 2002). The abundance estimation for Stratum X (Kiel Bight, a major part of Stratum E in the present study) was 588 ind. $(\mathrm{CV}=0.48)$, which corresponds to a density of 0.101 ind. $\mathrm{km}^{-2}$ (Hammond et al. 2002) and is similar to the density in the July 2004 survey of Stratum E (Kiel Bight), which was estimated at 0.13 ind. $\mathrm{km}^{-2}$ (95\% CI $=0.02$ to 0.38 ).

Densities for Stratum G (east of the Darss ridge) were very low, ranging from 0 to 0.008 ind. $\mathrm{km}^{-2}$ during all but 2 surveys (July 2002 and April 2005). In fact, in 8 of the 13 surveys of Stratum G no sightings were recorded despite considerable survey effort (Table 1c). An aerial survey in July 1995 estimated an abundance of 599 ind. $(\mathrm{CV}=0.57)$ for an area around the island of Bornholm (L. Hiby \& P. Lovell pers.comm.), which corresponds to a density of approximately $0.009 \mathrm{ind} . \mathrm{km}^{-2}$.

During our July 2002 survey an unusually high number of porpoises were seen east of the island of Rugen in Stratum G. The mean group size of 2.63 was the highest ever recorded during our surveys. The estimated density of 1.04 for Stratum G is associated with a very large confidence interval ( $95 \% \mathrm{CI}=0.07$ to 3.42 ) due to the patchy occurrence of the sightings, which caused a high variation in sighting rates between transects (Table 1).

Stranded porpoises are collected routinely along the German coastline (Siebert et al. 2006). It is interesting to note that from 2003 to 2006, no porpoises were reported from the area east of Rugen (H. Benke pers. comm.). However, in 2002, a total of 5 porpoises were found stranded or directly reported as bycatch by fishermen (H. Benke unpubl. data). This unusually high mortality in the German part of the Baltic Proper might be linked to the short-term local increase in the abundance of porpoises. The reasons for such relocation are unclear, but could be related to a change in food availability.

Apart from this unusual event in July 2002, the density of porpoises declined from west to east during all other study months and years, with the highest densities in Strata E and F and the lowest densities in Stratum G. These findings are consistent with the results of the SCANS survey in 1994 (Hammond et al. 2002). A decrease in frequency of strandings and incidental sightings (Siebert et al. 2006) and in relative occurrence (Scheidat et al. 2004) along the German coast from Schleswig-Holstein to Mecklenburg-Western Pomerania in the east has also been reported. Additionally, the frequency of porpoise click detections 
on stationary hydrophones (T-PODs) was shown to decrease from west to east (Verfuß et al. 2007).

During 10 surveys, all 3 strata were covered within 25 consecutive days, allowing the estimation of overall abundance. In March 2003, only a few sightings were made and the resulting low abundance estimate was associated with a large CV. For the remaining surveys in spring, abundances were low, with 1352 (March/ April 2005) and 1635 (April 2006) ind. All remaining estimates from May to September ranged between 1726 and 2905 ind. and had largely overlapping confidence intervals. We found no obvious seasonal patterns in our data, but we did not sample from October to February. Verfuß et al. (2007) showed seasonality in porpoise click activity in the German Baltic Sea, with the highest click activity recorded in spring and summer months.

\section{Estimating bycatch rates}

Rubsch \& Kock (2004) provide the only available estimate of porpoise bycatch along the German Baltic coast. They included data from stranded bycaught animals and bycatch reported directly by fishermen, as well as data from interviews with the local fishing community from the years 1996 to 2002. Their conclusion was that an estimated mean of 57 animals are caught in the German western Baltic (corresponding to Strata E and F) and 25 ind. are caught in the German Baltic Proper (corresponding to Stratum G) per year. Thus, when applying the total annual bycatch of 82 ind. to our abundance estimates for porpoises in the German Baltic Sea, bycatch rates can be calculated for each of the overall surveys (Table 2).

The results indicate that the lowest annual bycatch rate is $1.78 \%$. All bycatch rates calculated in this way exceed the recommendations for maximum sustainable bycatch of $1 \%$ in harbour porpoises given by the Bergen Declaration (ASCOBANS 2002) and by the International Whaling Commission (IWC 2000). It also exceeds the recommendation given in the Agreement on the Conservation of Small Cetaceans of the Baltic and North Seas (ASCOBANS) that annual porpoise bycatch in the fishery should not be higher than $1.7 \%$ of the respective population (ASCOBANS 2000). When using the lower confidence limit of the abundance estimates, as a precautionary principle would require, all bycatch rates are $>3.6 \%$. A further point to note is that our abundance estimates included Danish waters, whereas the bycatch estimate by Rubsch \& Kock (2004) did not include porpoises recorded on the Danish coast as bycatch. Therefore, these bycatch rates are likely minimum estimates. It is apparent that the aim to reduce bycatch rates to levels that would not risk a fur- ther decline or to allow the recovery of porpoise is not reached along the German coast.

Bycatch rates depend on many different factors, such as the fishing effort and method, the local abundance of porpoises, as well as their local distribution in relation to fishing activities. Thus, it is certain that bycatch will vary between seasons, as well as between years. The present estimates of bycatch for the western Baltic have no measure of precision. In the future, detailed studies on seasonal and regional differences in bycatch are needed, which could then be related to abundance estimates on the same spatial and temporal scales. Independent observer schemes are considered the only way to obtain reliable quantitative bycatch estimates (Northridge 1996, CEC 2002); recommendations for the design of monitoring schemes and for the best practises are given by Northridge (1996). However, the application of these recommendations will be difficult, due to the large number of small fishing operations in the Baltic Sea area, as there is little or no space on the vessels for observers.

As described in the 'Introduction', there is sufficient evidence to suggest that at least 2 different populations of porpoises occur in Baltic waters. The tentative demarcation line between these 2 populations lies in German waters. Our data show that, in most cases, the density of porpoises east of the Darss ridge is extremely low. A short-term migration of porpoises into this area (as probably seen in July 2002) can be considered an unusual event. In areas of very low densities, any visual survey will struggle to get reliable results; therefore, alternative monitoring methods, such as the use of passive acoustics, need to be further developed and standardised.

Berggren et al. (2002) have shown that porpoises from the sub-population east of the Darss and Linham ridges ('Baltic Proper') are bycaught at an unsustainable rate. Our results indicate that the fairly abundant animals of the western Baltic in the Kiel and Mecklenburg Bights face similar threats. Even though porpoise density is still fairly high compared to the Baltic Proper population, the estimated percentage of bycatch is cause for concern. It is also conceivable that the porpoise population in the western Baltic may depend on immigrants from other areas to maintain itself. If such a 'sink population' exists, the estimated bycatch rates might not be accurate until total abundance and bycatch for each particular population area have been estimated.

The effort of the aerial surveys between 2002 and 2006 was very high, resulting in reliable abundance estimates for the local populations of porpoises in the southwestern Baltic Sea. However, to estimate bycatch rates, it is very important to have access to equally reliable and precise bycatch numbers. None of the smaller 
vessels operating in the German Baltic Sea are covered by observer programs that are now implemented throughout the European Union (ICES 2007), and thus it is doubtful that the data collected within the EU observer program will be sufficient to estimate bycatch of porpoises in Baltic waters. The ASCOBANS recovery plan for harbour porpoises in the Baltic Sea (Jastarnia Plan) provides guidelines for the reduction of bycatch and proposes more research on porpoise population structure in the Baltic (ASCOBANS 2002). Potentially, these results could allow us to interpret the occurring bycatch on different temporal and spatial scales. This, in turn, would enable us to suggest the best measurement policies for mitigation and to increase the chances for survival of the harbour porpoise in all Baltic waters.

Acknowledgements. The data presented here were collected within the scope of projects funded by the following agencies: the German Federal Ministry of Food, Agriculture and Consumer Protection, the German Federal Ministry for the Environment, Nature Conservation and Nuclear Safety within the Investment-in-Future Program (ZIP) and the Federal Agency for Nature Conservation. We thank L. Hiby, P. Lovell and K. Kaschner for their help with data analyses. Our thanks go to P. Siemiatkowski from Syltair, L. Petersen from the Danish Air Survey, and S. Hecke from FLM Kiel. The completion of the surveys was only possible through the enthusiastic dedication of the observers and navigators J. Adams, P. Børjesson, D. Risch, A. Gomez, H. Herr, I. Kuklik, K. Lehnert, L. Lehnert, M. Marahrens, C. Rocholl, T. Walter, U. Westerberg and S. Zankl. We thank H. Giewat for maintaining and managing the database, and R. Mundry for programming several programs to facilitate statistical analyses. We also greatly appreciate the help of D. Borchers, L. Burt and F. Samarra, who provided the code for data and bootstrapping analyses. We thank L. Hiby and D. Borchers for reviewing the 'Materials and methods' section of this paper. We also thank S. Koschinski for his comments on an earlier version of the manuscript.

\section{LITERATURE CITED}

Andersen SH (1982) Change in occurrence of the harbour porpoise, Phocoena phocoena, in Danish waters as illustrated by catch statistics from 1834 to 1970 . Mammals Seas 4:131-133

Andersen LW (1993) The population structure of the harbour porpoise, Phocoena phocoena, in Danish waters and part of the North Atlantic. Mar Biol 116:1-7

ASCOBANS (Agreement on the Conservation of Small Cetaceans of the Baltic and North Seas) (2000) Resolution No. 3 Incidental Take of Small Cetaceans. 3rd Session of the Meeting of Parties, Bristol. 26-28 July 2000, p 93-96. www.service-board.de/ascobans_neu/files/2000-6.pdf

ASCOBANS (Agreement on the Conservation of Small Cetaceans of the Baltic and North Seas) (2002) Recovery Plan for Baltic harbour porpoises (Jastarnia Plan). ASCOBANS, Bonn. www.service-board.de/ascobans_neu/ files/recoveryplan.pdf

Beineke A, Siebert U, McLachlan M, Bruhn R and others (2005) Investigations of the potential influence of environmental contaminants on the thymus and spleen of harbor porpoises (Phocoena phocoena). Environ Sci Technol 39:3933-3938

Benke H, Siebert U, Lick R, Bandomir B, Weiss R (1998) The current status of harbour porpoises (Phocoena phocoena) in German waters. Arch Fish Mar Res 46:97-123

Berggren P (1994) Bycatches of the harbour porpoise (Phocoena phocoena) in the Swedish Skagerrak, Kattegat and Baltic Seas, 1973-1993. Rep Int Whal Comm (Spec Issue) 15:211-215

Berggren P, Arrhenius F (1995a) Sightings of harbour porpoises (Phocoena phocoena) in Swedish waters before 1990. Rep Int Whal Comm (Spec Issue) 16:99-108

Berggren P, Arrhenius F (1995b) Densities and seasonal distribution of harbour porpoises (Phocoena phocoena) in the Swedish Skagerrak, Kattegat and Baltic Seas. Rep Int Whal Comm (Spec Issue) 16:109-122

Berggren P, Ishaq R, Zebühr Y, Näf C, Bandh C, Broman D (1999) Patterns and levels of organochlorines (DDTs, PCBs, non-ortho PCBs and PCDD/Fs) in male harbour porpoises (Phocoena phocoena) from the Baltic Sea, the Kattegatt-Skagerrak Seas and the west coast of Norway. Mar Pollut Bull 38:1070-1084

> Berggren P, Wade PR, Carlström J, Read AJ (2002) Potential limits to anthropogenic mortality for harbour porpoises in the Baltic region. Biol Conserv 103:313-322

Børjesson P, Berggren P (1997) Morphometric comparisons of skulls of harbour porpoises (Phocoena phocoena) from the Baltic, Kattegat and Skagerrak Seas. Can J Zool 75: 280-287

Bruhn R, Kannan N, Petrick G, Schulz-Bull DE, Duinker JC (1999) Persistent chlorinated organic contaminants in harbour porpoises from the North Sea, the Baltic Sea and Arctic waters. Sci Total Environ 237/238:351-361

Buckland ST, Anderson DR, Burnham KP, Laake J, Thomas L (2001) Introduction to distance sampling: estimating abundance of biological populations. Oxford University Press, New York

Burnham KP, Anderson DR, Laake JL (1980) Estimation of density from line transect sampling of biological populations. Wildl Monogr 72:3-202

CEC (Commission of the European Communities) (2002) Incidental catches of small cetaceans. In: Report of the meeting of the subgroup on fishery and the environment (SGFEN) of the Scientific, Technical and Economic Committee for Fisheries (STECF). SEC(2002) 376, CEC, Brussels, p 83

Christensen O (1991) Bycatches in the salmon drift net fishery in the Baltic Sea. International Council for the Exploration of the Sea, Anadromous and Catadromous Fish Committee, ICES CM M:26

Das K, Vossen A, Tolley K, Vikingsson G and others (2006) Interfollicular fibrosis on the thyroid glands of the harbour porpoise (Phocoena phocoena): an endocrine disruption? Arch Environ Contam Toxicol 51:720-729

Fonselius SH (1974) Oceanografi. Generalstabens Litografiska Anstalts förslag, Stockholm

Hammond PS, Benke H, Berggren P, Borchers DL and others (1995) Distribution and abundance of the harbour porpoise and other small cetaceans in the North Sea and adjacent waters. Final Report to the European Commission under contract LIFE 92-2/UK/027, Brussels

> Hammond PS, Benke H, Berggren P, Borchers DL and others (2002) Abundance of harbour porpoise and other cetaceans in the North Sea and adjacent waters. J Appl Ecol 39:361-376

Hiby AR (1999) The objective identification of duplicate sightings in aerial survey for porpoise. In: Garner GW, 
Amstrup SC, Laake JL, Manly BFJ, McDonald LL, Robertson DG (eds) Marine mammal survey and assessment methods. Balkema, Rotterdam, p 179-189

Hiby AR, Hammond PS (1989) Survey techniques for estimating the abundance of cetaceans. Rep Int Whal Comm 11(Spec Issue):47?80

Hiby AR, Lovell P (1998) Using aircraft in tandem formation to estimate abundance of harbour porpoise. Biometrics 54: $1280-1289$

Huggenberger S, Benke H, Kinze CC (2002) Geographical variation in harbour porpoise (Phocoena phocoena) skulls: support for a separate non-migratory population in the Baltic Proper. Ophelia 56:1-12

ICES (International Council on the Exploration of the Sea) (2007) Report of the Working Group on Marine Mammal Ecology (WGMME). ICES CM ACE:03. www.ices.dk/ reports/ACE/2007/WGMME07.pdf

IWC (International Whaling Commission) (2000) Report of the IWC-ASCOBANS working group on harbour porpoise. J Cet Res Manag 2(Suppl):297-305

Kinze CC (1985) Intraspecific variation in Baltic and North Sea harbour porpoises (Phocoena phocoena (L. 1758)). Vidensk Medd Dan Nathist Foren 146:63-74

Kinze CC (1994) Incidental catches of harbour porpoises (Phocoena phocoena) in Danish waters 1986-89. Rep Int Whal Comm (Spec Issue) 15:183-188

Kock KH, Benke H (1996) On the by-catch of harbour porpoise (Phocoena phocoena) in German fisheries in the Baltic and the North Sea. Arch Fish Mar Res 44:95-114

Koschinski S (2002) Current knowledge on harbour porpoises (Phocoena phocoena) in the Baltic Sea. Ophelia 55: 167-197

Määttänen K (1990) Occurrence of harbour porpoises Phocoena phocoena in Finnish waters. In: Evans PGH, Aguilar A, Smeenk C (eds) European research on cetaceans, Vol 6. European Cetacean Society, Cambridge, p 55-58

Northridge SP (1996) A review of marine mammal bycatch observer schemes with recommendations for best practice. JNCC Report 219, Joint Nature Conservation Committee, Aberdeen

Rubsch S, Kock KH (2004) German part-time fishermen in the Baltic Sea and their bycatch of harbour porpoise. ASCOBANS 11th Advisory Meeting, Jastrzebia Góra, 27-29 April, 2004. Doc AC11/Doc10 (P) www.serviceboard.de/ascobans_neu/files/ac11-10.pdf

Editorial responsibility: Helene Marsh,

Townsville, Queensland, Australia
Scheidat M, Kock KH, Siebert U (2004) Summer distribution of harbour porpoise (Phocoena phocoena) in the German North and Baltic Sea. J Cet Res Manag 6:251-257

Siebert U, Joiris C, Holsbeek L, Benke H, Failing K, Frese K, Petzinger E (1999) Potential relation between mercury concentrations and necropsy findings in cetaceans from German waters of the North and Baltic Seas. Mar Pollut Bull 38:285-295

Siebert U, Wünschmann A, Weiss R, Frank H, Benke H, Frese $\mathrm{K}$ (2001) Post mortem findings in harbour porpoises (Phocoena phocoena) from the German North and Baltic Sea. J Comp Pathol 124:102-114

> Siebert U, Gilles A, Lucke K, Ludwig M, Benke H, Kock $\mathrm{KH}$, Scheidat M (2006) A decade of harbour porpoise occurrence in German waters: analyses of aerial surveys, incidental sightings and strandings. J Sea Res 56: $65-80$

Skóra KE (1991) Notes on Cetacea observed in the Polish Baltic Sea 1979-1990. Aquat Mamm 17:67-70

Skóra KE, Pawliczka I, Klinowska M (1988) Observations of the harbour porpoise Phocoena phocoena on the Polish Baltic coast. Aquat Mamm 14:113-119

Teilmann J, Lowry N (1996) Status of the harbour porpoise (Phocoena phocoena) in Danish waters. Rep Int Whal Comm 46:619-625

Tiedemann R, Harder J, Gmeiner RC, Haase E (1996) Mitochondrial DNA sequence patterns of harbour porpoises (Phocoena phocoena) from the North and the Baltic Sea. Z Säugetierkd 61:104-111

- Verfuß UK, Honnef CG, Meding A, Dähne M, Mundry R, Benke H (2007) Geographical and seasonal variation of harbour porpoise (Phocoena phocoena) presence in the German Baltic Sea revealed by passive acoustic monitoring. J Mar Biol Assoc UK 87:165-176

Voipio A (1981) The Baltic Sea. Elsevier Oceanography Series 30, Elsevier, Amsterdam

Wang JY, Berggren P (1997) Mitochondrial DNA analyses of harbour porpoises (Phocoena phocoena) in the Baltic Sea, the Kattegat and Skagerrak Seas and off the west coast of Norway. Mar Biol 127:531-537

Wünschmann A, Siebert U, Frese K, Weiss R and others (2001) Evidence of infectious diseases in harbour porpoises (Phocoena phocoena) hunted in the waters of Greenland and by-caught in the German North and Baltic Sea. Vet Rec 148:715-772

Submitted: September 13, 2007; Accepted: October 13, 2008 Proofs received from author(s): November 24, 2008 